\title{
Evaluation of the selected economic parameters of Czech companies and their potential for overcoming global crises during the Covid-19 pandemic
}

\author{
Michal Kudej \\ Faculty of Business Administration, \\ Prague University of Economics and Business, \\ Prague, Crech Republic \\ michal.kudej@vss.cr.
}

\author{
Beata Gavurova \\ Center for Applied Economic Research, \\ Faculty of Management and Economics, \\ Tomas Bata University in Zlin, \\ Zlin, Crech Republic \\ gavurova@utb.cz.
}

\section{Zuzana Rowland \\ Institute of Technology and Business, \\ School of Expertness and Valuation, \\ Céské Budéjovice, Czech Republic \\ rowland@mail.vstecb.cr.}

\begin{abstract}
The aim of the study is to evaluate the potential of Czech companies in overcoming the pandemic crisis caused by Covid-19 on the basis of the selected economic parameters. To achieve this aim, development of Czech companies in the period of 2004-2018 has been analysed, which includes the periods before and during the financial crisis and the period of Czech economy growth. A thorough analysis of this period allows us to create an evaluation platform and formulate the assumptions as to what extent Czech companies are able to cope with another crisis caused by the Covid-19 pandemic. The research sample consists of 25,501 financially stable Czech companies of various sizes. 184,548 pieces of financial data from these companies are analysed using standard statistical methods, namely Kruskal-Wallis test. The results of the analyses show that in the case of Czech companies, the hypothesis of a significant impact of the financial crisis and the subsequent long recovery period is not confirmed. Czech companies show a relatively high resilience to the effects of the financial crisis of 2008 and the ability to overcome this crisis. Government measures to support the economy will play an important role in crisis management processes, enabling
\end{abstract}

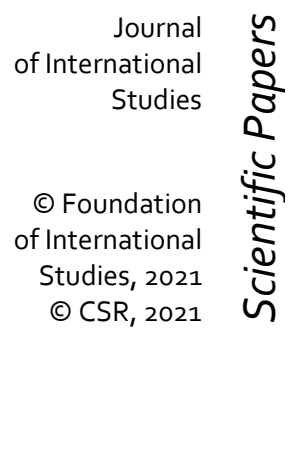

national

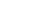

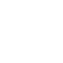


companies to survive in the worst stages of their operation and thus bridge the period of revenue losses and other negatives associated with the crisis. Based on the evaluation of the post-crisis development, we can state that Czech companies with appropriate government support will be able to overcome the negative consequences of the pandemic crisis caused by Covid-19. The results of the study have several implications for policy-making and are also beneficial for the development of a methodological platform and the creation of national and international benchmarking indicators.

Keywords: financial crisis, pandemic crisis, bankruptcy, financial indicators, financial stability, government support.

JEL Classification: G01, G33, G38

\section{INTRODUCTION}

The development of Czech companies from 2004 to 2018 can be divided into the three periods. The first period was since the entry of Czech Republic into the European Union until the outbreak of the financial crisis in 2008, the second period was the period during the financial crisis, and the third one is the so-called post-crisis period. In the post-crisis period, Czech companies recovered, and the economy made gradual progress. Although there are several institutional reports at the national and international levels dealing with quantifying the impact of the crisis on the countries' economies, a few reports have analysed the ways to cope with the crisis and the activities of companies and governments that have helped to revive the economy with active policies (Mazzanti et al., 2020; Čizo et al., 2020; Škare \& Porada-Rochoń, 2020).

Currently, the global economic environment is affected by the pandemic crisis caused by Covid-19, which has hit countries on a global scale. Although many international institutions have crisis scenarios and are initiating support for the development of the business environment, the pandemic crisis has been unexpected and assessing its development and impact is highly problematic due to the lack of experience with pandemic crises and uncertainties in prediction (Cepel et al., 2020; Korshenko et al., 2020, Scott et al., 2020). We can consider a crisis to be any undesirable development or a situation in which crucial positions and measures need to be taken. The current pandemic crisis caused by Covid-19 has brought strong interventions and constraints to the world's economies, with both European and non-European countries not having prepared crisis economic scenarios to address its negative consequences (Zeibote et al., 2019; Dvorsky et al., 2020).

In the event of the financial crisis in 2008, Czech government as well as the governments of other countries took several measures to support the economy and entrepreneurs, which partially compensated for the shortfalls in businesses' incomes and thus significantly helped to prevent many bankruptcies. Many areas within Czech economy are not managed centrally, so proactivity and creativity from individual companies were also expected. We can expect that the financial situation of Czech companies will deteriorate significantly as a result of the still ongoing pandemic crisis.

The aforementioned facts were the major source of motivation for us to carry out this research, the aim of which is to evaluate the potential of Czech companies in overcoming the pandemic crisis caused by Covid-19 on the basis of the selected economic parameters. To achieve the goal of the research, we have chosen the research sample consisting of Czech companies of various sizes, which have not had any negative events in their history. In other words, we have focused on the companies with sufficient financial stability and good financial condition. 
The structure of the study is as follows: In the overview of the studies, both foreign and Czech, we tried to reveal and scrutinize the relations between the financial crisis and the economic aspects of SMEs development. The analytical part has focused on the development of Czech companies during the period of 2004 - 2018, which included the periods before and during the financial crisis and the period of Czech economy growth. In the conclusion we evaluate the obtained results and formulate important implications for the relevant policies.

\section{LITERATURE REVIEW}

Several international research teams were examining the impact of the financial crisis and government interventions (e.g. Škare Porada-Rochoń et al. 2020; Cepel et al. 2020; Hahn et al. 2020; Lăzăroiu et al. 2020; Degryse et al. 2018; Kinnunen et al. 2021). Their research studies were quite heterogeneous in terms of research processes, but they revealed many factors affecting economic processes in companies as well as in the economies of countries. The political and economic implications offered by the studies were a valuable platform for formulating recommendations to government policy and strategy makers, as well as for conducting follow-up research. The main focus of this research was on the studies related to the recent financial crisis, as well as the current pandemic crisis.

Cornille et al. (2019) examined the heterogeneous effects of credit restrictions on employment during the European sovereign debt crisis. As an exogenous determinant of companies' approach to credit, the authors used the parameter variability of banks' financial health after the crisis in 2008 . The results of the analyses showed that SMEs that borrowed financial resources from financially less-sound banks had credit restrictions, which also affected the number of employees in companies. Credit constraints were unfavourable for employment in SMEs, who also had demand problems during the crisis and faced strong product market competition. The study pointed to the importance of short-term compensation programs that will ensure the sustainability of jobs in SMEs during a recession. In their study, Degryse et al. (2018), who monitored the sensitivity of bank loans to SMEs in the United Kingdom, also pointed out the problems of SMEs' access to credit in the period before and after the financial crisis. In the pre-crisis period, banks' financial conditions did not affect the availability of credit, regardless of the distance between a bank branch and its headquarters. During the crisis, SMEs had better access to credit from banks that were in the vicinity of SMEs and were more financially stable. The results of the study pointed to the tendency to prefer the use of banking services - loans - in times of crisis directly from the headquarters of the banks, not from their branches. The latest OECD study (2020) presented in detail the development of SME financing policies ten years after the financial and economic crisis. The study distinguished the stages of the so-called immediate post-crisis period (2008 - 2011), the early recovery years (from 2012) and the latest political trends. It is also important to map the regulatory environment for SME financing. From a retrospective point of view, evaluation reports of SMEs' approaches to finance, which are regularly prepared, are also very important for the evaluation of the development of SME financing and the evaluation of set policies. The study provided a valuable platform for international benchmarking and can be useful for the creation and evaluation of national policies in the field of SME financing and their preparation for economic as well as non-economic crises. Ghulam (2019) in his study also pointed out the problems of obtaining loans for SMEs during the global financial crisis. The author examined the importance of various factors as well as the macroeconomic, financial and banking environment to identify whether companies were able to gain access to external finances during the financial crisis. They used Heckman's selection approach to model supply and demand. The results of the analyses showed that young and small companies were most likely to reject a loan application. The risk of rejection also increased with a decrease in government support, guarantees, etc. The resolution of SME insolvencies also had a significant impact on the likelihood of SME 
loan rejection. The study emphasised the role and influence of the government in strengthening the position of SMEs in times of financial crisis. Papaoikonomou et al. (2017) examined the strategic responses of SMEs to the financial and economic crisis in Catalonia. The authors examined in detail the institutional, behavioural and political issues that are necessary to understand the principles of operation of an entrepreneurial society. Important societal themes include exploring the relationship between formal and informal institutions, entrepreneurial choice, entrepreneurial behaviour, orientation and success, entrepreneurial finance, social dimensions and results, growth and the economic crisis (Kitrar \& Lipkind, 2021). It is proved that such intangible factor of success as entrepreneur's belief in the mission of the business can be more efficient driver of performance than financial motives of activity (Belás et al., 2018). In their study, Sung Hee and Suk-Pil (2018) addressed the issue of debt policies for Korean SMEs after the US financial crisis in 2007. These authors also pointed to significant obstacles to financing Korean SMEs over a 10-year period, with 1,501 SMEs from KOSPI and KOSDAQ markets making up the research sample. SMEs were divided into four groups. The authors did not find convincing evidence that SMEs adjust their debt levels to the optimal level. The study concluded that both trade-off and pecking order theories partially explain Korean SMEs' financial policies but not entirely. The authors acknowledged that their models do not sufficiently represent the varieties of SMEs' characteristics and encourage the creation of follow-up research in this area. Yamori (2015) pointed out the importance of the credit guarantee system after the global financial crisis in his study. Its aim was to explain the Japanese public credit guarantee system and its role during the global financial crisis. The author used the methodology of a questionnary research among SMEs, where the research sample was created by those SMEs which were most affected by the crisis. Aichi-ken Credit Guarantee Corporation also participated in the research. The analyses results show that the credit guarantee system was effective at the protection of the economy from the collapse. The author stated that this system was so generous that now almost all SMEs want it to remain unchanged. On the other hand, it has brought heavy financial burdens to the Japanese government, which may result in lower incentives for companies and banks to increase their efficiency. The author appealed to the need to create reforms limiting the target and the guarantee coverage. Eichacker (2017) examined the effects of financial architecture and German funding on European crises. The financial liberalization of the euro area supported the creation of a new market for German financial institutions, which has increased the risk of a crisis. The author stated that in 2008, when the global financial crisis occurred, German losses on international secured assets prompted a retrenchment of domestic and international lending. This also paved the way for the eurozone's sovereign debt crisis. For this reason, the author appealed to the need for a thorough examination of the role of financial liberalization in facilitating German and European financial crises. They saw this as one of the effective ways to prepare for the effects of a crisis in the future and to be able to eliminate all those possible risks, which could result in a huge increase in national, European and global costs, in due time. Cohen et al. (2015) examined the impact of the financial crisis on changes in the internal processes of SMEs. An analysis of 161 SMEs showed that various aspects of the financial crisis have led SMEs to adjust their management accounting systems. There had also been a significant increase in the number of SMEs that have started to apply budgeting and calculation systems for various management purposes, for measuring performance, etc. Juergensen et al. (2020) examined how the covid-19 pandemic affected different types of manufacturing SMEs. In the short term, in addition to the interruption of demand, most SMEs also had problems in the area of logistics, although the level of transportation problems varied in different sectors. Covid-19 has had a strong negative impact on value chains, with rapid changes in the economy caused by the pandemic causing an economic shock to most SMEs. The authors strongly called for the need for such policy interventions, which would be more sensitive to different SMEs. Therefore, no universal approach can be applied to support SMEs. The innovative behaviour of manufacturing companies is also affected by the pandemic (Koszowska-Mojsa, 2020). Park and García- 
Herrero (2020) draw attention to the fact that a pandemic has a strong negative economic impact from an international perspective. The authors pointed out that more than 100,000 cases of Covid-19 are registered in many countries, so the economic impact in densely populated countries is difficult to quantify in the short term. Kassema (2020) debated over whether the covid-19 pandemic is a health crisis, an economic crisis, or both an economic and health crisis. The author mapped the development of the pandemic and its impact on societies, communities, organizations, as well as the public sector. The author formulated several valuable recommendations for sustainable development and economic growth in the post-crisis period. This topic is followed by the study by Vaishali et al. (2020), who examined and evaluated the impacts of Covid-19 in countries. According to the authors, Covid-19 did not discriminate between religious beliefs, gender, political barriers and other geoclimatic boundaries. Rommer et al. (2020) also pointed out the crisis behaviour of people and their importance in overcoming the effects of the crisis. Zubair et al. (2020) examined the real effects of the financial crisis on private companies in the Netherlands. SME investment fell sharply during and after the financial crisis. The authors found that investments during the crisis were less dependent on internal finances than on external ones. The conclusions showed that loans from banks were a decisive factor in determining the investments of SMEs during the financial crisis in 2008-2009. Magrizos et al. (2020) dealt with the issue of corporate social responsibility in times of economic crisis and points to the fact that corporate social responsibility in the crisis period receives insufficient attention even from researchers. The authors examined the extent to which corporate social responsibility activities in south-eastern Europe can be developed during the economic crisis and what benefits this can have for society and the economy. The results showed recommendations for corporate social responsibility procedures that would be appropriate to use in times of crisis. Huang and Ju (2010) applied cluster analysis to assess the post-crisis activity of SMEs in China in 2009. Although SMEs in China were hit hard by the financial crisis in 2007-2008, economic indicators and growth indices of SMEs in China began to improve significantly in 2009, which was a signal for a strong recovery of the country 's economy through SMEs. Simeonova-Ganeva et al. (2013) decided to examine the situation in the SME sector in the post-crisis period, using data from SMEs of the EU-27. The analysis focused on key factors for sustainable development and competitiveness. The methodology used also made it possible to carry out a comparative analysis between different segments of SMEs and reveal their internal dynamics. The conclusions showed that the industry will be stable to the extent as to which there will be stable companies operating in it. Therefore, it is also important to provide short-term government aid for those SMEs that need it in the post-crisis period. Mayr et al. (2020) draw attention to the fact that SMEs have significant problems in the post-crisis period almost everywhere worldwide. Therefore, it is important to identify the basic elements of a sustainable reorganization of SMEs in order to ensure the long-term survival and competitiveness of companies and eliminate their bankruptcy. The credit problems of SMEs related to the economic crisis are also closely linked to the performance of banks. This fact is also pointed out by Saddique et al. (2017) who examined the impact of financial variables on bank performance before and after the financial crisis in Pakistan. The results of the analyses confirmed that the financial crisis in 2008 significantly affected the performance of banks, which also affected the development of the economy and, secondarily, SMEs. Hahn et al. (2020) also justified the importance of the scientific community in overcoming the effects of the Covid-19 pandemic and defined a number of recommendations in order to share knowledge from other countries and helped to create different stabilization mechanisms for economies. Ayuba et al. (2020) pointed to the importance of not only economic but also psychological factors in the internal processes of SMEs and the need for their in-depth examination, as they can have a significant influence in the decision-making processes of managers. Although the economic crisis has grown to international proportions, it is important to examine the microview as well as to focus on assessing the profound psychological impact of the recession on workplaces in companies. The Hermann study also pointed to a new area of research - socio-analysis, which is important 
in the study and analysis of the phenomena of money, finance, capital with respect to the behaviour of citizens and financial institutions. According to the authors, the psychoanalytic perspective can be applied in the study of other economic and social problems in the crisis and post-crisis period. These findings also correspond to the results of a study by Fotinatos -Ventouratos and Cooper (2015), which quantified the effects of the global economic crisis in 2008. The authors examined the long-term impact of the crisis on workplaces in the future, the effects of recession on companies and individuals. According to the authors, even though the economic crisis has grown to international proportions, it is important to examine not only macroeconomic indicators but also microeconomic indicators and to focus on assessing the deep psychological impact of the recession on workplaces in companies.

The activities of international institutions are also a significant support for the creation of political implications in countries in crisis and post-crisis periods (OECD, 2020, 2013). The OECD report (2013) monitored SMEs' access to financing over time and evaluated several indicators from 25 countries. The report also presented trends and conditions of financing with an emphasis on the changes that occurred in 2010-2011, as well as an assessment of government policy responses to improving SMEs' access to financing. Amber and Saikat (2017) created a systematic review of 121 empirical articles to examine SME performance factors. The authors pointed out the need for constant research of SMEs and the effects on their performance in order to reveal other determinants of their development and performance improvement. In conclusion, they evaluated that so far, no comprehensive model has been proposed for analysing the relationships between important constructs that comprehensively affect the performance of SMEs. In addition to mentioned factors of development and performance, the crisis in the labour market in the surrounding of SMEs activity should considered as it was an important factor of entrepreneurial success even before the pandemic crisis (Bilan et al, 2020), especially for immature markets (Mishchuk et al., 2020). At the time of the Covid-19 crisis, examining the performance and survival of SMEs is an important research domain. In relation to the current pandemic crisis caused by Covid-19, Welbrum et al. (2020) stated that policy makers have responded by introducing a policy of social distancing and the introduction of quarantine. Under the weight of significant business disruptions, reduced supply and demand, and distuption of supply chains, the health crisis could result in a deep economic downturn. In addition to the health crisis, the concurrence of severe economic losses and historical levels of corporate debt may trigger a financial crisis. According to some scenarios, with long-term stringent measures, they estimated an exceptional level of risk of corporate failure to double to three times the financial crisis in 2008. Sharif et al (2020) analysed the link between the recent expansion of COVID-19, the shock from oil price volatility, the stock market, geopolitical risk, and US economic policy uncertainty. They revealed the unprecedented impact of COVID-19 and oil price shocks on the level of geopolitical risk, economic policy uncertainty and stock market volatility. The impact of COVID-19 on geopolitical risk is significantly higher than on US economic uncertainty. COVID-19 risk is perceived differently in the short and long term and may primarily be perceived as an economic crisis.

\section{DATA AND METHODOLOGY}

The dataset used for analytical purposes contains 184,548 pieces of financial data obtained from 25,501 companies in the Czech Republic. Of this number, 41,686 pieces of financial data relate to 3,729 large companies and 142,862 pieces of financial data relate to 21,878 small and medium-sized enterprises. Data was obtained from publicly available sources, namely the Bisnode Magnus web system (www.bisnode.sk). 
Table 1

General view of the dataset

\begin{tabular}{|c|c|c|c|c|c|}
\hline Year & $\begin{array}{c}\text { Large } \\
\text { Companies (LC) }\end{array}$ & $\begin{array}{c}\text { Small and } \\
\text { Medium } \\
\text { Enterprises } \\
\text { (SME) }\end{array}$ & Total & $\begin{array}{c}\text { Large } \\
\text { Companies (LC) } \\
\%\end{array}$ & $\begin{array}{c}\text { Small and } \\
\text { Medium } \\
\text { Enterprises } \\
(\text { SME) } \%\end{array}$ \\
\hline 2004 & 2,028 & 7,492 & 9,520 & 21.3 & 78.7 \\
\hline 2005 & 2,158 & 8,477 & 10,635 & 20.3 & 79.7 \\
\hline 2006 & 2,338 & 9,427 & 11,765 & 19.9 & 80.1 \\
\hline 2007 & 2,540 & 10,000 & 12,540 & 20.3 & 79.7 \\
\hline 2008 & 2,680 & 9,999 & 12,679 & 21.1 & 78.9 \\
\hline 2009 & 2,701 & 9,996 & 12,697 & 21.3 & 78.7 \\
\hline 2010 & 2,834 & 9,997 & 12,831 & 22.1 & 77.9 \\
\hline 2011 & 2,927 & 9,998 & 12,925 & 22.6 & 77.4 \\
\hline 2012 & 2,994 & 9,999 & 12,993 & 23.0 & 77.0 \\
\hline 2013 & 3,067 & 10,000 & 13,067 & 23.5 & 76.5 \\
\hline 2014 & 3,144 & 9,997 & 13,141 & 23.9 & 76.1 \\
\hline 2015 & 3,187 & 9,999 & 13,186 & 24.2 & 75.8 \\
\hline 2016 & 3,174 & 9,993 & 13,167 & 24.1 & 75.9 \\
\hline 2017 & 2,812 & 8,306 & 11,118 & 25.3 & 74.7 \\
\hline 2018 & 3,102 & 9,182 & 12,284 & 25.3 & 74.7 \\
\hline Total & $\mathbf{4 1 , 6 8 6}$ & $\mathbf{1 4 2 , 8 6 2}$ & $\mathbf{1 8 4 , 5 4 8}$ & $\mathbf{2 2 . 6}$ & $\mathbf{7 7 . 4}$ \\
\hline
\end{tabular}

Source: own processing

The data in the dataset was divided into three periods. The first period is the period before the financial crisis, which represents the years of 2004-2008, the second period is the period of the financial crisis, which represents the years of 2009-2013, and the third is the period after the financial crisis defined by 2014 2018. At the same time, the dataset is divided into a section containing large companies (LC) and a section containing small and medium-sized enterprises (SMEs) (Table 1).

For the purpose of the analysis, ratios were determined in the data set, which characterize the company's operating performance, profitability of assets and debt ratio. In the area of operating performance, it is primarily the operating margin of performance, determined as the share of operating profit and total performance, the total margin of performance, determined as the share of total profit and loss. In the area of profitability, the operating profitability of assets is determined as the ratio of operating profit and total assets, and the return on equity is determined as the ratio of total profit and equity. As an indicator of debt ratio, total debt ratio was chosen, determined as the share of external capital on total assets. In all cases, these are quantitative variables. Dichotomic and categorical variables were also created in the dataset. Dichotomic variables were created for selected indicators, for which it is telling whether their value is positive or negative, i.e., they represent the polarity of selected indicators. The polarity was determined for the operating and total profit or loss as an indicator of the company's profitability or loss and then for equity.

Due to the fact that ratios, as continuous variables, show a number of outlying and extreme values, their categories were created for selected ratios, using interval sorting, where the continuous values were sorted into intervals of the same frequency. Then the number of intervals was determined according to Sturges' rule. Thus, new categorical (ordinal) variables were created in the file, which eliminate the mentioned outlying and extreme values, as these are part of the first and last interval, namely the first and last categories. 
As a baseline analysis, a comparison of the files was performed, which represents a comparison of groups of values in terms of their properties, expressed either by a certain position characteristic or by the overall distribution of the frequencies of the values. The comparison of files was performed for selected variables in individual analysed periods, in the form of testing hypotheses about the agreement of the frequency distribution of values. Due to the result of the test of normality of distribution and also due to the presence of dichotomous and ordinal variables, nonparametric tests were used to compare groups, namely the Kruskal-Wallis test, which is used to test the hypothesis of agreement of frequency distribution of values of selected variables (Řezanková, 2017). The research also used statistical methods for the analysis of quantitative continuous and categorical variables. A 5\% reduced average was used for the analysis of quantitative continuous variables. The reason for using the $5 \%$ reduced average is the presence of several outlying and extreme values in the set, which are partially eliminated by this approach, as $5 \%$ of the extreme values are not included in the average. Due to the outlying and extreme values in the set, in addition to the average, the median was used for analysis, which is a suitable measure of the central tendency in the case where the data contains outlying and extreme values (Hendl, 2015).

Boxplots were used for the analysis of categorical variables created on the basis of selected quantitative continuous variables, enabling the analysis of data using quartiles. If there are no outlying and extreme values in the set (which are eliminated by the creation of categorical variables), then in the interval determined by the lower and upper edges of the box (i.e., the lower and upper quartile) there are $50 \%$ of values (Řezanková, 2017). Using boxplots, the distribution of categories of selected indicators was analysed, i.e., categorical ordinal variables that replace the original quantitative continuous variable in the set. At this point, it is worth noting that the categories of selected ratios were determined so that the higher the category, the better the value of the indicator. As part of the analysis of these categorical variables, the interquartile range was also monitored, which is a characteristic of dispersion that is used together with quartiles to describe the distribution of data (Hendl, 2015). Quantitative analysis was performed in IBM SPSS Statistics, version 25.

\section{RESULTS AND DISCUSSION}

For the analysis of quantitative variables, it is necessary to test the normality of the data distribution, in order to determine whether parametric tests can be used for the analyses. This test is performed using the Kolmogorov-Smirnov test. The normality test was applied to the variables mentioned above (Table 2).

Table 2

Normality test

\begin{tabular}{|l|c|c|c|}
\hline & \multicolumn{3}{|c|}{ Kolmogorov-Smirnov } \\
\hline & Statistic & df & Sig. \\
\hline Operating performance margin & 0.495 & 184,031 & 0.000 \\
\hline Total performance margin & 0.495 & 184,048 & 0.000 \\
\hline Total debt ratio & 0.413 & 184,224 & 0.000 \\
\hline Operating profitability of assets & 0.402 & 184,171 & 0.000 \\
\hline Return on equity & 0.468 & 183,992 & 0.000 \\
\hline
\end{tabular}

Source: own processing

Based on the normality test, it was found out that for all variables it is necessary to reject the hypothesis of normality of data distribution. It follows that it is not possible to use parametric tests that require a normal distribution for further analysis of these variables. 
In the first step, the files were compared according to individual periods (cycle phases) for selected financial indicators. The subject of the comparison of sets are directly quantitative variables expressing the basic financial characteristics of companies (Table 3).

Table 3

Testing of file compliance hypotheses - selected financial characteristics

\begin{tabular}{|l|l|l|l|}
\hline \multicolumn{1}{|c|}{ Null hypothesis } & \multicolumn{1}{c|}{ Test } & Sig. & \multicolumn{1}{c|}{ Decision } \\
\hline $\begin{array}{l}\text { Operating performance } \\
\text { margin }\end{array}$ & Independent-Samples Kruskal-Wallis Test & 0.000 & Reject the null hypothesis. \\
\hline Total performance margin & Independent-Samples Kruskal-Wallis Test & 0.000 & Reject the null hypothesis. \\
\hline Total debt ratio & Independent-Samples Kruskal-Wallis Test & 0.000 & Reject the null hypothesis. \\
\hline $\begin{array}{l}\text { Operating profitability of } \\
\text { assets }\end{array}$ & Independent-Samples Kruskal-Wallis Test & 0.000 & Reject the null hypothesis. \\
\hline Return on equity & Independent-Samples Kruskal-Wallis Test & 0.000 & Reject the null hypothesis. \\
\hline
\end{tabular}

Source: own processing

A comparison of the files shows that for all variables, the hypothesis of compliance in individual periods must be rejected. Thus, the basic financial characteristics of companies differ in individual periods.

Furthermore, a comparison of files was performed for dichotomous variables expressing whether a company is profitable or loss-making and whether it has positive or negative equity (Table 4).

Table 4

Testing of file compliance hypotheses - polarity of selected financial indicators

\begin{tabular}{|l|l|c|l|}
\hline \multicolumn{1}{|c|}{ Null Hypothesis } & \multicolumn{1}{|c|}{ Test } & Sig. & \multicolumn{1}{c|}{ Decision } \\
\hline Polarity of equity & $\begin{array}{l}\text { Independent-Samples Kruskal-Wallis } \\
\text { Test }\end{array}$ & 0.000 & Reject the null hypothesis. \\
\hline Polarity of operating profit & $\begin{array}{l}\text { Independent-Samples Kruskal-Wallis } \\
\text { Test }\end{array}$ & 0.000 & Reject the null hypothesis. \\
\hline Polarity of profit before tax & $\begin{array}{l}\text { Independent-Samples Kruskal-Wallis } \\
\text { Test }\end{array}$ & 0.000 & Reject the null hypothesis. \\
\hline
\end{tabular}

Source: own processing

Even in this case, based on the Kruskal-Wallis test, the hypothesis of the compliance of the data set have to be rejected.

The last comparison of files by period was performed for categorical variables, created on the basis of interval classification for the original quantitative continuous variables, which (as already mentioned) eliminate outlying and extreme values (Table 5).

Table 5

Testing of file compliance hypotheses - categories of selected indicators

\begin{tabular}{|l|l|l|l|}
\hline \multicolumn{1}{|c|}{ Null Hypothesis } & \multicolumn{1}{|c|}{ Test } & \multicolumn{1}{|c|}{ Sig. } & \multicolumn{1}{|c|}{ Decision } \\
\hline Polarity of equity & $\begin{array}{l}\text { Independent-Samples Kruskal-Wallis } \\
\text { Test }\end{array}$ & 0.000 & Reject the null hypothesis. \\
\hline Polarity of operating profit & $\begin{array}{l}\text { Independent-Samples Kruskal-Wallis } \\
\text { Test }\end{array}$ & 0.000 & Reject the null hypothesis. \\
\hline Polarity of profit before tax & $\begin{array}{l}\text { Independent-Samples Kruskal-Wallis } \\
\text { Test }\end{array}$ & 0.000 & Reject the null hypothesis. \\
\hline
\end{tabular}

Source: own processing 
Even in the case of categorical variables, where outlying and extreme values are eliminated on the basis of the Kruskal-Wallis test, it is necessary to reject the hypothesis of file compliance.

\subsection{Basic financial characteristics according to economic development}

This part contains an analysis of the basic financial characteristics of companies by period divided by the size of the companies.

Table 6

Averages and median profit margins according to economic development and company size

\begin{tabular}{|c|c|c|c|c|c|}
\hline Indicator & Company size & Parameter & $\begin{array}{c}\text { Period } \\
\text { before the } \\
\text { financial } \\
\text { crisis }(\%)\end{array}$ & $\begin{array}{l}\text { Period of } \\
\text { financial } \\
\text { crisis }(\%)\end{array}$ & $\begin{array}{l}\text { Period after } \\
\text { financial } \\
\text { crisis }(\%)\end{array}$ \\
\hline \multirow{4}{*}{$\begin{array}{l}\text { Operating } \\
\text { performance } \\
\text { margin }\end{array}$} & \multirow{2}{*}{$\begin{array}{l}\text { Large companies } \\
\text { (LC) }\end{array}$} & 5\% Trimmed Mean & 5.8 & 5.2 & 6.0 \\
\hline & & Median & 4.8 & 4.2 & 4.8 \\
\hline & \multirow{2}{*}{$\begin{array}{l}\text { Small and medium } \\
\text { enterprises (SME) }\end{array}$} & 5\% Trimmed Mean & 6.3 & 5.0 & 6.3 \\
\hline & & Median & 4.6 & 3.5 & 4.5 \\
\hline \multirow{4}{*}{$\begin{array}{l}\text { Total performance } \\
\text { margin }\end{array}$} & \multirow{2}{*}{$\begin{array}{l}\text { Larce companies } \\
\text { (LC) }\end{array}$} & 5\% Trimmed Mean & 4.0 & 3.9 & 4.7 \\
\hline & & Median & 3.1 & 3.0 & 3.7 \\
\hline & \multirow{2}{*}{$\begin{array}{l}\text { Small and medium } \\
\text { enterprises (SME) }\end{array}$} & 5\% Trimmed Mean & 4.4 & 3.4 & 4.6 \\
\hline & & Median & 3.0 & 2.2 & 3.1 \\
\hline
\end{tabular}

Source: own processing

Overall, it is clear that in terms of margins, they decreased during the financial crisis, but subsequently the situation returned to pre-crisis or even higher levels (Table 6). A more significant impact is seen for small and medium-sized enterprises. The difference in the impact of the financial crisis is not large and it is clear that small and medium-sized enterprises forming the core of the Czech economy have shown the ability to cope with the crisis as well as large companies from which more sophisticated risk management systems can be expected.

Table 7

Averages and median debt ratio according to economic development and company size

\begin{tabular}{|c|l|c|c|c|c|}
\hline \multirow{2}{*}{ Indicator } & \multicolumn{1}{|c|}{ Company size } & Parameter & $\begin{array}{c}\text { Period } \\
\text { before the } \\
\text { financial } \\
\text { crisis (\%) }\end{array}$ & $\begin{array}{c}\text { Period of } \\
\text { financial } \\
\text { crisis (\%) }\end{array}$ & $\begin{array}{c}\text { Period after } \\
\text { financial } \\
\text { crisis (\%) }\end{array}$ \\
\hline \multirow{5}{*}{ Total debt ratio } & $\begin{array}{l}\text { Large companies } \\
(\text { LC) }\end{array}$ & $\begin{array}{c}5 \% \text { Trimmed } \\
\text { Mean }\end{array}$ & 54.3 & 49.3 & 47.1 \\
\cline { 2 - 6 } & Small and medium & Median & 54.6 & 49.1 & 46.7 \\
\cline { 2 - 6 } & enterprises (SME) & Mean & 56.8 & 50.0 & 44.9 \\
\cline { 2 - 6 } & & Median & 57.7 & 48.6 & 43.1 \\
\hline
\end{tabular}

Source: own processing

Debt analysis yielded several interesting results (Table 7). Debt ratio for both large and small and medium-sized enterprises fell during the financial crisis and did not return to pre-crisis levels after the financial crisis. Given that the main source of external long-term sources of financing for Czech companies is bank loans, it can be assumed that due to the financial crisis and its impact on banks, the loan volume of banks has decreased. In the case of small and medium-sized enterprises, the aspect of personal liability for 
loans by the owners of these enterprises, who are mostly managers at the same time, could also have an impact (small and medium-sized enterprises in the Czech Republic are mostly owner-managed enterprises). Overall, it can be stated that during the financial crisis and after it subsided, the debt ratio of Czech companies decreased on average.

Table 8

Averages and median of profitability according to economic development and company size

\begin{tabular}{|c|c|c|c|c|c|}
\hline Indicator & Company size & Parameter & $\begin{array}{l}\text { Period } \\
\text { before the } \\
\text { financial } \\
\text { crisis }(\%)\end{array}$ & $\begin{array}{l}\text { Period of } \\
\text { financial } \\
\text { crisis }(\%)\end{array}$ & $\begin{array}{l}\text { Period after } \\
\text { financial } \\
\text { crisis }(\%)\end{array}$ \\
\hline \multirow{4}{*}{$\begin{array}{l}\text { Operating } \\
\text { profitability of assets }\end{array}$} & \multirow{2}{*}{$\begin{array}{l}\text { Large companies } \\
\text { (LC) }\end{array}$} & 5\% Trimmed Mean & 8.8 & 7.2 & 8.2 \\
\hline & & Median & 7.3 & 6.0 & 6.8 \\
\hline & \multirow{2}{*}{$\begin{array}{l}\text { Small and } \\
\text { medium } \\
\text { enterprises (SME) }\end{array}$} & 5\% Trimmed Mean & 11.6 & 7.8 & 9.2 \\
\hline & & Median & 9.0 & 5.7 & 6.8 \\
\hline \multirow{4}{*}{ Return on equity } & \multirow{2}{*}{$\begin{array}{l}\text { Large } \\
\text { companies(LC) }\end{array}$} & 5\% Trimmed Mean & 15.8 & 12.1 & 13.8 \\
\hline & & Median & 13.0 & 9.7 & 10.9 \\
\hline & \multirow{2}{*}{$\begin{array}{l}\text { Small and } \\
\text { medium } \\
\text { enterprises(SME) }\end{array}$} & 5\% Trimmed Mean & 23.5 & 13.9 & 14.8 \\
\hline & & Median & 18.0 & 9.2 & 10.3 \\
\hline
\end{tabular}

Source: own processing

The operating profitability of assets shows a more significant impact on small and medium-sized enterprises than on large ones, which is related to a similar situation in the area of margins (Table 8). At the same time, a decline from a higher level of profitability can be seen for small and medium-sized enterprises. At the same time, in contrast to margins, neither large nor small and medium-sized enterprises returned to pre-crisis levels. A similar situation is with the return on equity, where it is also clear that small and mediumsized enterprises experienced a more significant impact of the financial crisis, namely a larger decline from original levels. Even the return on equity did not return to pre-crisis levels in the period after the financial crisis. Overall, due to the financial crisis, profitability decreased, but not to an alarming level. Thus, despite the financial crisis, Czech companies have undoubtedly maintained their investment attractiveness.

\subsection{Polarity of selected indicators}

Subsequently, an analysis of the polarity of selected indicators was performed, which shows the development of the frequency of positive and negative values according to individual periods (Table 9).

Table9

Polarity of operating profit according to the size of the company

\begin{tabular}{|c|l|c|c|c|}
\hline \multicolumn{1}{|c|}{ Company size } & \multicolumn{1}{|c|}{ Indicator } & $\begin{array}{c}\text { Before the } \\
\text { financial crisis } \\
(\%)\end{array}$ & $\begin{array}{c}\text { Financial } \\
\text { crisis (\%) }\end{array}$ & $\begin{array}{c}\text { After the } \\
\text { financial crisis } \\
(\%)\end{array}$ \\
\hline \multirow{2}{*}{ Large companies (LC) } & Positive operating profit & 87.7 & 86.8 & 90.2 \\
\cline { 2 - 5 } & Negative operating profit & 12.3 & 13.2 & 9.8 \\
\hline $\begin{array}{l}\text { Small and medium } \\
\text { enterprises (SME) }\end{array}$ & Positive operating profit & 87.4 & 81.7 & 87.4 \\
\cline { 2 - 5 } & Negative operating profit & 12.6 & 18.3 & 12.6 \\
\hline
\end{tabular}

Source: own processing 
The analysis shows that most of the companies, regardless of size, achieved an operating profit throughout the entire monitored period. For large companies, a minimal impact of the financial crisis on operating profitability can be seen, in contrast to small and medium-sized enterprises, where the impact is more pronounced, and a larger number of small and medium-sized enterprises fell into loss at the operating level during the financial crisis. For large companies, it is clear that after the financial crisis, there were more profitable companies in this category at the operational level than before the financial crisis. For small and medium-sized enterprises, the number of loss-making enterprises at the operating level returned to precrisis levels.

Table 10

Polarity of the total economic result according to the size of the company

\begin{tabular}{|l|l|c|c|c|}
\hline \multicolumn{1}{|c|}{ Company size } & \multicolumn{1}{|c|}{ Indicator } & $\begin{array}{c}\text { Before the } \\
\text { financial crisis } \\
(\%)\end{array}$ & $\begin{array}{c}\text { Financial } \\
\text { crisis (\%) }\end{array}$ & $\begin{array}{c}\text { After the } \\
\text { financial crisis } \\
(\%)\end{array}$ \\
\hline Large companies (LC) & $\begin{array}{l}\text { Positive economic result } \\
\text { before tax }\end{array}$ & 86.6 & 84.9 & 89.4 \\
\hline & $\begin{array}{l}\text { Negative economic result } \\
\text { before tax }\end{array}$ & 13.4 & 15.1 & 10.6 \\
\hline $\begin{array}{l}\text { Small and medium enterprises } \\
\text { (SME) }\end{array}$ & $\begin{array}{l}\text { Positive economic result } \\
\text { before tax }\end{array}$ & 86.4 & 79.7 & 86.0 \\
\hline & $\begin{array}{l}\text { Negative economic result } \\
\text { before tax }\end{array}$ & 13.6 & 20.3 & 14.0 \\
\hline
\end{tabular}

Source: own processing

In terms of development, the situation with the overall economic result is identical to the operating result (Table 10). Overall, however, a larger number of companies is noticeable, which achieved a loss at the overall level. Even for large companies, a more significant impact on the overall economic result is evident than in the case of the operating result. Therefore, the cause must be sought in the financial part of the income statement, resp. in the financial result of management.

Table 11

Frequencies of equity polarity according to the size of the company

\begin{tabular}{|l|l|c|c|c|}
\hline \multicolumn{1}{|c|}{ Company size } & \multicolumn{1}{|c|}{ Indicator } & $\begin{array}{c}\text { Before the } \\
\text { financial crisis } \\
(\%)\end{array}$ & $\begin{array}{c}\text { Financial } \\
\text { crisis (\%) }\end{array}$ & $\begin{array}{c}\text { After the } \\
\text { financial crisis } \\
(\%)\end{array}$ \\
\hline Large companies (LC) & Positive equity & 97.5 & 98.2 & 99.6 \\
\hline $\begin{array}{l}\text { Small and medium enterprises } \\
\text { (SME) }\end{array}$ & Negative equity & 2.5 & 1.8 & 0.4 \\
\hline & Positive equity & 94.5 & 94.4 & 98.6 \\
\hline & Negative equity & 5.5 & 5.6 & 1.4 \\
\hline
\end{tabular}

Source: own processing

The polarity of equity or negative equity is primarily an indication of possible over-indebtedness (Table 11). For large companies, such an indication was quite minimal, and during the financial crisis, the number of large companies with negative equity decreased even further. It can therefore be stated that in the case of large companies, which have not had any negative events in their history, and thus entered the period of financial crisis in relatively good condition, the financial crisis did neither have an effect on the polarity of equity, nor on the rise of the number of companies with negative equity. In the period after the financial crisis, the number of companies with negative equity decreased further. For small and medium-sized enterprises, the share of enterprises with negative equity remained almost the same during the financial crisis 
and decreased (as was the case for large enterprises) in the post-crisis period. It can therefore be stated that companies that did not show any negative events in their history survived the financial crisis in terms of the polarity of equity without any problems and in the following period the situation improved even more.

\subsection{Categories of selected indicators}

The following analysis deals with the categories of selected financial characteristics. As it was already mentioned, the categories, or categorical variables, are based on the original quantitative variables, but eliminate outlying and extreme values. The analysis was performed using boxplots, for individual periods according to the size of the company. The first to be analysed was the operating margin of performance; the categories of operating output margin by period and by company size (Chart 1).

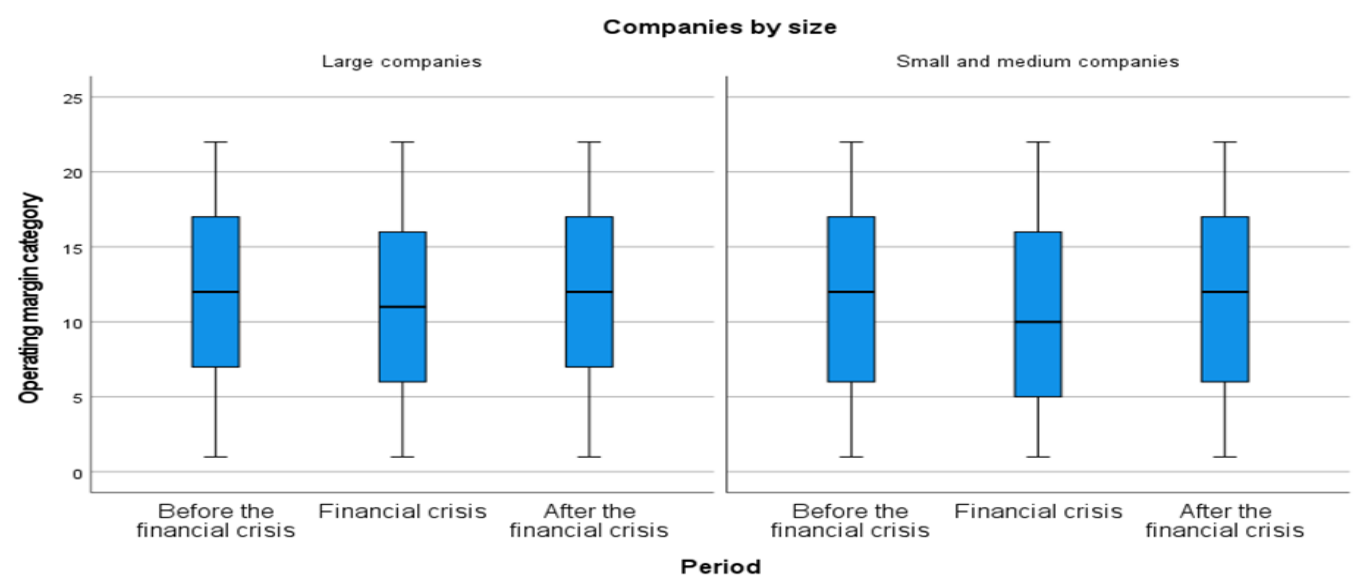

Chart 1. Categories of performance operating margin

Source: own processing

The results of the analysis of the operating performance margin categories confirm the previous conclusions based on the average and the median. For large companies, there is a noticeable shift in both the box and the median during the financial crisis, i.e., $50 \%$ of the values and the median reached a lower level. However, it subsequently returned to the previous level. The situation is similar for small and mediumsized enterprises, but a larger inter-quartile margin is evident, which means that $50 \%$ of the values are in a wider range. Higher dispersion and standard deviation are also evident for SMEs.

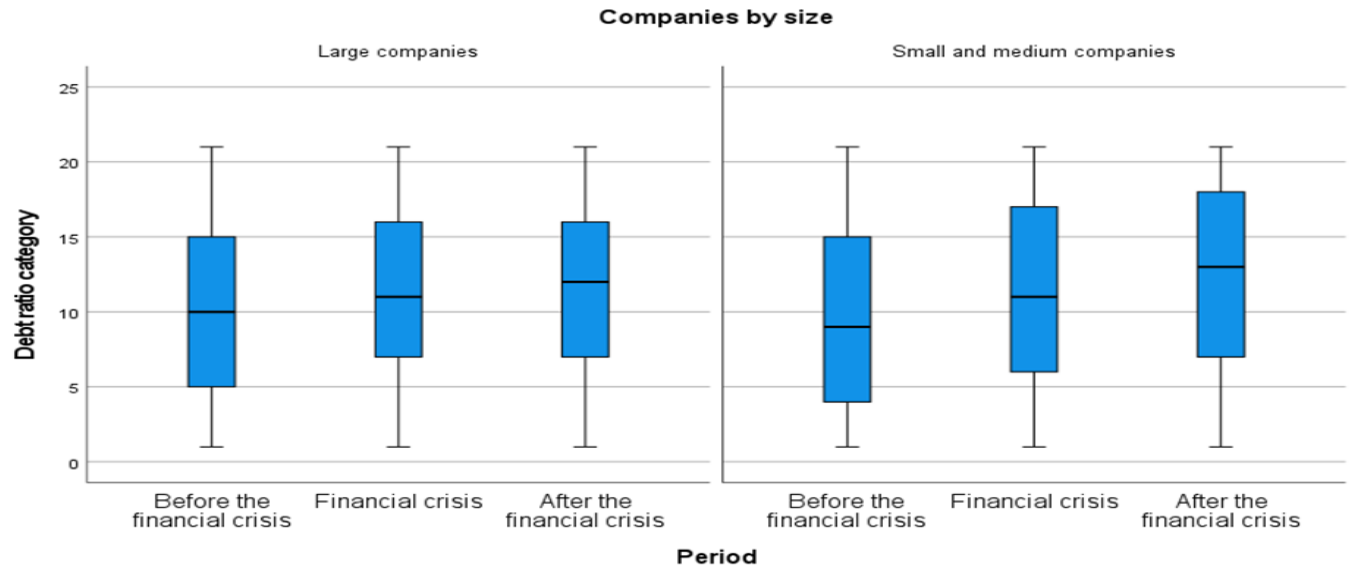

Chart 2. Categories of total debt ratio

Source: own processing 
Similarly, for debt ratio and debt ratio categories, the results of the analysis using boxplots confirm the previous conclusions based on the average and the median (Chart 2). Both types of companies saw a reduction in debt during the financial crisis, which persisted for the following period. During the financial crisis, the interquartile margin decreased. This remained the same in the post-crisis period, but it is clear there was a shift of the median in the post-crisis period. As in the previous case, a larger interquartile margin is evident for SMEs, and the dispersion and standard deviation are also higher. Unlike large enterprises, small and medium-sized enterprises show a shift of the box towards higher values at the same interquartile range, and thus there is a shift of both the lower and upper quartiles. Debt ratio for SMEs has increased further in the post-financial crisis period, with $50 \%$ of the category values at higher levels than during the financial crisis.

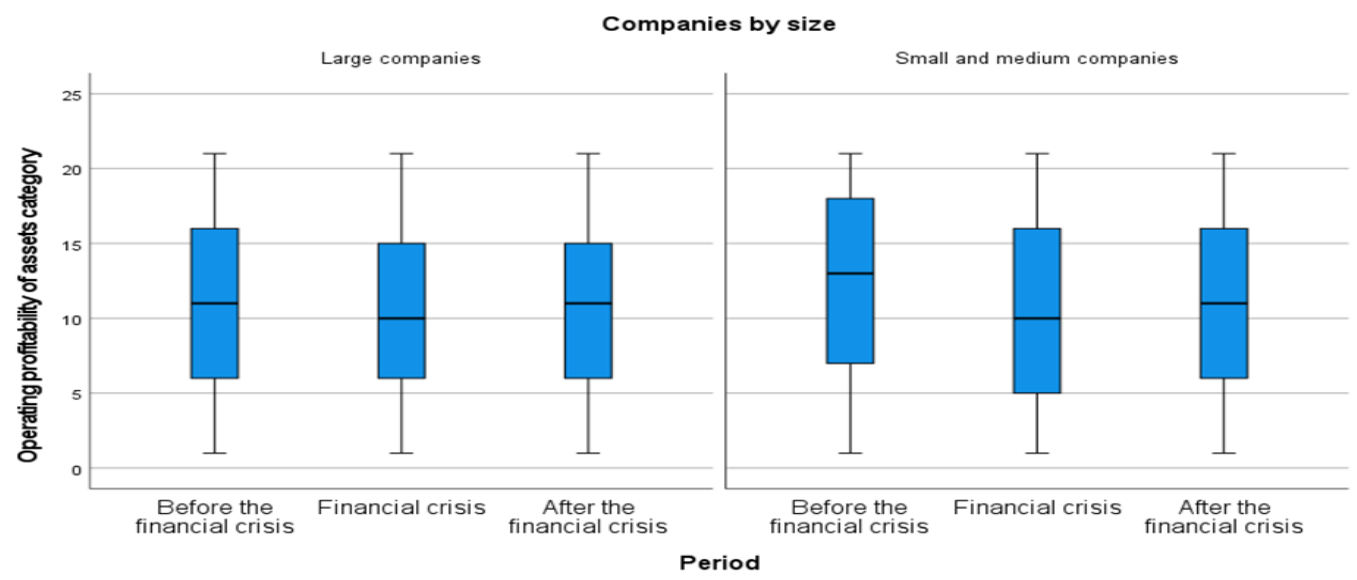

Chart 3. Operating profitability of assets

Source: own processing

Also, for the operating profitability of assets, or the categories of operating profitability of assets, the results of the analysis using boxplots confirm the previous conclusions (Chart 3). It is clear that for large companies during the financial crisis, the interquartile spread decreased due to the shift of the upper quartile towards worse values. This situation persists even in the period after the financial crisis, with a slight increase in the median in this period. Thus, for large companies, it is clear that both during the financial crisis and after it subsided, $50 \%$ of the values of the categories of the indicator of operating profitability of assets are "condensed" at slightly lower levels than in the period before the financial crisis. For SMEs, (as in the previous two cases) a higher interquartile margin is evident. However, for these companies there was an overall shift of the box during the financial crisis towards lower values under the same interquartile range, i.e., there was a shift in both the upper and lower quartiles. In the period after the financial crisis, the interquartile margin of small and medium-sized enterprises narrowed due to the shift of the lower quartile to a higher level, which is, however, still lower than in the period before the financial crisis. In the period after the financial crisis, $50 \%$ of the values of the categories of the operating profitability of assets indicator are also "condensed" to levels that are lower than in the period before the crisis.

The above-mentioned results show that Czech companies that have not had any negative events in their history dealt with the financial crisis of 2008 relatively problem-free. The hypothesis of a significant impact of the crisis on the financial characteristics of companies, their performance and profitability were not confirmed in the examined Czech companies. It is important to evaluate these findings with the results of studies that also analysed other research samples of Czech companies. For example, studies by Schönfeld (2020) and Schönfeld et al. (2019) analysed companies that were affected by the negative events of the corporate crisis. The authors conclude that, for example, in companies that applied for a moratorium, the 
symptoms of the corporate crisis had already started manifesting themselves three years before. It was therefore a matter of time before the unresolved corporate crisis reached the stage where its outcome was the bankruptcy of the company. For such companies, it is likely that the current situation will rather accelerate their demise.

The results of our analyses create a valuable platform for the development of new methodological procedures that would be able to assess the degree of financial stability of companies and resilience to crises with different course, duration and impact. For this reason, it is essential to share research knowledge with international research teams and to build a strong data and analytical platform. The numerous creditworthiness and bankruptcy models used so far work with many limitations, and many of them are exposed to the danger of obsolescence and the need for regular updating. The obsolescence of models is not only affected by the method used, but also by external factors. Their impact must be subjected to scientific scrutiny.

\section{CONCLUSION}

Each economic crisis raises several questions related to the existence of companies in economic sectors and at the same time encourages the development of methodological procedures that would be able to make the most reliable forecasts of the development of companies as well as the economy as a whole. We are currently facing a global pandemic crisis, also referred to as a health and economic crisis, whose scenarios of development and impact are very unclear. It is very problematic to forecast developments in heterogeneous systems, such as the economies of individual countries. It is no longer possible to apply models that have been used so far due to their obsolescence or irrelevancy in terms of time and the effects of external factors that need to be constantly examined. Also, the legal regulations defining the conditions for declaring bankruptcy in the Czech Republic are different from other countries.

Reflecting on these facts, the aim of our study was to evaluate the potential of Czech companies in overcoming the effects of the current pandemic crisis caused by Covid-19 on the basis of selected economic parameters from the previous crisis period. It is clear from the results of the analyses that Czech companies, which have not had any negative events in their history, coped with the financial crisis of 2008 relatively well without existential problems. The hypothesis of a significant impact of the crisis on the financial characteristics of companies, their performance and profitability has not been confirmed for Czech companies. The decline in the performance of Czech companies measured by the analysed margins and the subsequent profitability of total assets and equity logically worsened after the outbreak of the financial crisis, but the decline was not fatal and subsequently stabilized and returned to satisfactory levels. On the contrary, the debt ratio, which is one of the important indications of a company's possible bankruptcy, has improved. Czech companies thus stabilized during and after the financial crisis. A similar situation accompanied Czech banks, which, compared to banks in the European Union or the United States, did not experience any major (existential) problems during the financial crisis, which can be attributed to the stabilization of the banking sector in the previous period before the privatization of Czech banks and the tightening of regulations by the Czech National Bank. It was this fact that could also help Czech companies, as their dominant financing institutions were able to continue to function without any problems.

Based on the results of the analyses, we can formulate the assumption that given the way in which Czech companies coped with the financial crisis in 2008 and its effects, these companies could cope relatively well with the crisis caused by the Covid-19 pandemic. Government measures to support the economy will always play an important role in this process, which should help alleviate the economic shock of companies caused by the introduction of health protection measures. This will also apply to other countries affected by the pandemic crisis. Negative expectations of economic entities and their behaviour 
in the economic system are also important. The role of psychological factors, which are analysed only very rarely in studies evaluating the crisis and post-crisis development of companies, is thus also brought to the attention.

The follow-up research analysing the economic impacts of the Covid-19 pandemic on the stability and functioning of Czech companies will also focus on examining psychological factors, government interventions and their impact on companies coping with the effects of the pandemic crisis.

The results of this study provide valuable information for the creation of national and international benchmarks in this area and support the development of methodological procedures for assessing the stability of companies to overcome obstacles to economic and non-economic crises of a global nature. They will also provide valuable information for national policy makers as well as experts involved in the development of national and regional strategic plans. In the research area, the obtained results will support the creation of national and international benchmarks and the implementation of comparative analyses in this area. This will create a strong support mechanism for developing new and improving existing methodologies aimed at quantifying the economic as well as non-economic impacts of pandemic as well as financial crises.

\section{ACKNOWLEDGEMENT}

The research was supported by the Research and Development Agency GAAA under the contract No. 21/2020: "Management, business risk and the firm bankruptcy in the segment of SMEs".

\section{REFERENCES}

Ayua, A., Saad, N., \& Zainol, A. (2020). Perceived Service Orientation, Economic Factors, Psychological Factors and Tax Compliance: Evidence From Nigerian SMEs. Malaysian Management Journal, 20, 41-57. https://doi.org/10.32890/mmj.20.2016.9040

Belás, J., Dvorský, J., Kubálek, J., \& Smrčka, L. (2018). Important factors of financial risk in the SME segment. Journal of International Studies, 11(1), 80-92. doi:10.14254/2071-8330.2018/11-1/6

Bilan, Y., Mishchuk, H., Roshchyk, I., \& Joshi, O. (2020). Hiring and retaining skilled employees in SMEs: problems in human resource practices and links with organizational success. Business: Theory and Practice, 21(2), 780-791. DOI: https://doi.org/10.3846/btp.2020.12750

Cepel, M., Gavurova, B., Dvorsky, J., \& Belas, J. (2020). The impact of the COVID-19 crisis on the perception of business risk in the SME segment. Journal of International Studies, 13(3), 248-263. doi:10.14254/20718330.2020/13-3/16.

Čizo, E., Ignatjeva, S., \& Lavrinenko, O. (2020). Determinants of financial development of the EU countries in the period 1995-2017. Insights into Regional Development, 2(2), 505-522. https://doi.org/10.9770/IRD.2020.2.2(1)

Cohen, S., Karatzimas, S., \& Naoum, V.CH. (2015). Management Accounting Systems in SMEs: A Means to Adapt to the Financial Crisis? In: D. Vrontis, E. Tsoukatos and A. Maiza (eds) Innovative management perspectives on confronting contemporary challenges. Cambridge: Cambridge Scholars Publishing, 5681. https://ssrn.com/abstract $=2400328$ or http://dx.doi.org/10.2139/ssrn. 2400328

Cornille, D., Rycx, F., \& Tojerow, I. (2019). Heterogeneous effects of credit constraints on SMEs' employment: Evidence from the European sovereign debt crisis. Journal of Financial Stability, 41, 1-13. https://doi.org/10.1016/j.jfs.2019.02.001

Degryse, H., Matthews, K., \& Zhao, T. (2018). SMEs and access to bank credit: Evidence on the regional propagation of the financial crisis in the UK. Lournal of Financial Stability, 38, 53-70. https://doi.org/10.1016/i.jfs.2018.08.006

Dvorsky, J., Belas, J., Novotna, I., Fero, M., \& Petrakova, Z. (2020). Quality of Business Environment of the SME: A Sectoral View. Communications - Scientific Letters of the University of Zilina, 22(4), 163-172. https://doi.org/10.26552/com.C.2020.4.163-172 
Eichacker, N. (2017). Chapter 6: German financialization, the global financial crisis, and the Eurozone crisis. Liberalization, Integration, and Asymmetric State Power. Chapter 6. Monograph Book, pp. 192. https://doi.org/10.4337/9781786432032.

Fotinatos-Ventouratos, R., \& Cooper, C. L. (2015). The economic crisis and occupational stress. Edward Elgar Publishing., number 14738.

Ghulam, Y. (2019). SMEs Credit Conditions during the Financial Crisis in Europe. Prague Economic Papers, 28(1):105125. doi: $10.18267 /$ j.pep. 672 .

Hahn, U., Lagnado, D., Lewandowsky, S., \& Chater, N. (2020). Crisis knowledge management: Reconfiguring the behavioural science community for rapid responding in the Covid-19 crisis.

https://doi.org/10.31234/osf.io/hsxdk

Hendl, J. (2015). Přehled statistických metod: Analýza a metaanalýza dat.

Huang, D., \& Ju, K. (2010). The Impact of Financial Crisis on Chinese SMEs: Based on Dynamic Cluster Analysis of the Growth Indexes of SMEs in China Market. 2010 International Conference on Management and Service Science, Wuhan, 2010, 1-5. doi: 10.1109/ICMSS.2010.5576563.

Juergensen, J., Guimón, J., \& Narula, R. (2020). European SMEs amidst the COVID-19 crisis: Assessing impact and policy responses. J. Ind. Bus. Econ. 47, 499-510. https://doi.org/10.1007/s40812-020-00169-4

Kassema, J. J. (2020). COVID-19 Outbreak: Is It a Health Crisis or Economic Crisis or Both? Case of African Counties. Development Economic: Macroeconomic Issues in Development Economies eJournal, 9(51). http://dx.doi.org/10.2139/ssrn.3559200

Kaszowska-Mojsa, J. (2020). Innovation strategies of manufacturing companies during expansions and slowdowns. Entrepreneurial Business and Economics Review, 8(4), 47-66. https://doi.org/10.15678/EBER.2020.080403

Kinnunen, J., Georgescu, I., Hosseini, Z., \& Androniceanu, A.-M. (2021). Dynamic indexing and clustering of government strategies to mitigate Covid-19. Entrepreneurial Business and Economics Review, 9(2), ahead-of-print

Kitrar, L., \& Lipkind, T. (2021). The relationship of economic sentiment and GDP growth in Russia in light of the Covid-19 crisis. Entrepreneurial Business and Economics Review, 9(1), 7-29. https://doi.org/10.15678/EBER.2021.090101

Korshenkov, E., \& Ignatyev, S. 2020. Empirical interpretation and measurement of the productivity and efficiency of regions: The case of Latvia. Insights into Regional Development, 2(2), 549-561. https://doi.org/10.9770/IRD.2020.2.2(4)

Lăzăroiu, G., Horák, J., \& Valášková, K. (2020). Scaring ourselves to death in the time of COVID-19: Pandemic awareness, virus anxiety, and contagious fear. Linguistic and Philosophical Investigations, 19, 114-120. https://doi.org/10.22381/LPI1920208

Magrizos S, Apospori E, Carrigan M, \& Jones R. (2020). Is CSR the panacea for SMEs? A study of socially responsible SMEs during economic crisis. European Management Journal. doi:10.1016/j.emj.2020.06.002

Mayr, S., Mitter, Ch., \& Aichmayr, A. (2016). Corporate Crisis and Sustainable Reorganization: Evidence from Bankrupt Austrian SMEs. Journal of Small Business Management, 55(1). doi: 10.1111/jsbm.12248

Mazzanti, M., Mazzarano, M., Pronti, A., Quatrosi, M. (2020). Fiscal policies, public investments and wellbeing: mapping the evolution of the EU. Insights into Regional Development, 2(4), 725-749. http://doi.org/10.9770/IRD.2020.2.4(1)

Mishchuk, H., Bilan, S., Yurchyk, H., Akimova, L., \& Navickas, M. (2020). Impact of the shadow economy on social safety: The experience of Ukraine. Economics and Sociology, 13(2), 284-298.doi:10.14254/2071-789X.2020/132/19

OECD. (2013). Measures to finance SMEs in France, as a response to the crisis of 2008-09, in Country Profiles of SME Financing 2007-11, OECD Publishing, Paris, https://doi.org/10.1787/fin_sme_ent-2013-table54-en.

OECD. (2020). Policy developments in SME finance a decade after the global financial and economic crisis, in Financing SMEs and Entrepreneurs 2020: An OECD Scoreboard, OECD Publishing, Paris. https://doi.org/10.1787/6bdd4eb7-en.

Papaoikonomou, E., Li, X., \& Segarra, P. (2017). Exploring SMEs' strategic response to the financial and economic crisis: empirical evidence from Catalonia. Chapter 15. Monograph Book. Exploring the Entrepreneurial Society. 
Institutions, Behaviors and Outcomes. Ed. Bonnet, J., Dejardin, M. García-Pérez-De-Lema, D., p. 288. eISBN: 9781783472666. doi: https://doi.org/10.4337/9781783472666.

Park, A., \& Garcia-Herrero, A. (2020). An Emerging Crisis: The COVID-19 Pandemic Is Having a Powerful Effect on Emerging Markets. Available at SSRN. https://ssrn.com/abstract $=3676850$ or http://dx.doi.org/10.2139/ssrn.3676850

Řezanková, H. (2017). Analýza dat z dotazníkových šetření. Professional Publishing.

Rommer, D., Majerová, J., \& Machová, V. (2020). Repeated COVID-19 pandemic-related media consumption: Minimizing sharing of nonsensical misinformation through health literacy and critical thinking. Linguistic and Philosophical Investigations, 19, 107-113. https://doi.org/10.22381/LPI1920207

Saddique, A., Ahmad, M., Mumtaz, R., \& Arif, M. (2016). The Effect of Financial Variables on Bank Performance Pre and Post Financial Crisis.Journal of Finance and Accounting, 4(6),378-382. doi: 10.11648/j.jfa.20160406.18

Sayal, A., \& Banerjee, S. (2017). Factors influencing performance of SMEs: Literature review and research propositions for SMEs. The Marketing Review, 17(1), 3-32. https://doi.org/10.1362/146934717X14909733966083

Schönfeld, J. (2020). Financial situation of pre-packed insolvencies. Journal of Business Economics and Management, 21(4), 1111-1127. https://doi.org/10.3846/jbem.2020.12820

Schönfeld, J., Kuděj, M., \& Smrčka, L. (2019). Finanční charakteristiky podniků před vyhlášením moratoria. Politická ekonomie, 67(5), 490-510. https://doi.org/10.18267/i.polek.1247

Scott, R., Poliak, M., Vrbka, J., \& Nica, E. (2020). COVID-19 response and recovery in smart sustainable city governance and management: Data-driven Internet of Things systems and Machine Learning-based analytics. Geopolitics, History, and International Relations, 12(2), 16-22. http:/ /dx.doi.org/10.22381/GHIR12220202

Sharif, A., Aloui, C., \& Yarovaya, L. (2020). COVID-19 pandemic, oil prices, stock market, geopolitical risk and policy uncertainty nexus in the US economy: Fresh evidence from the wavelet-based approach. International Review of Financial Analysis, 70. https://doi.org/10.1016/j.irfa.2020.101496

Simeonova-Ganeva, R., Z. Vladimirov, M. Boeva, N. Panayotova, K. Ganev and R. Peneva (2011) Analysis of the Situation and Factors for Development of SMEs in Bulgaria: SMEs in the Crisis Context, BSMEPA, Noema, Sofia. Available at SSRN: https://ssrn.com/abstract=2290717 or http://dx.doi.org/10.2139/ssrn.2290717

Škare, M., \& Porada-Rochoń, M. (2020). Forecasting financial cycles: can big data help? Tecbnological and Economic Development of Economy, 26(5), 974-988. https://doi.org/10.3846/tede.2020.12702

Škare, M., \& Porada-Rochoń, M. (2020). The synchronisation between financial and business cycles: a cross spectral analysis view. Technological and Economic Development of Economy, 26(4), 907-919. https://doi.org/10.3846/tede.2020.12567

Sung Hee, L., \& Suk-Pil, L. (2018). Debt Policies for Korean SMEs After the US Financial Crisis in 2007. Available at SSRN: https://ssrn.com/abstract $=3285680$ or http://dx.doi.org/10.2139/ssrn.3285680

Vaishali, D. T., Pravin, P., \& Shinde, A. (2020). Are we prepared for the crisis? Reflection on crisis behaviour. JCR, 7(10), 44-47. doi:10.31838/jcr.07.10.10

Welburn, J. W., Strong, A., \& Social, R. (2020). Estimating the Impact of COVID-19 on Corporate Default Risk. Working Paper, 1-17.

Yamori, N. (2015). Japanese SMEs and the credit guarantee system after the global financial crisis. Cogent Economics \& Finance, 3(1), 1002600. https://doi.org/10.1080/23322039.2014.1002600

Zeibote, Z., Volkova, T., \& Todorov, K. 2019. The impact of globalization on regional development and competitiveness: cases of selected regions. Insights into Regional Development, 1(1), 33-47. https://doi.org/10.9770/ird.2019.1.1(3)

Zubair, S., Kabir, R., \& Huang, X. (2020). Does the financial crisis change the effect of financing on investment? Evidence from private SMEs. Journal of Business Research, 110, 456-463. https://doi.org/10.1016/j.jbusres.2020.01.063. 